\title{
Demographic Factors of Corporate E-learning among E-learners in an Oil and Gas Company
}

\author{
Sharmini Marilyn Balakrishnan', Mohd Hazwan Mohd Puad²*, Habibah Ab Jalil ${ }^{3}$ \\ ${ }^{123}$ Faculty of Educational Studies, Universiti Putra Malaysia, 43400 UPM Serdang, Selangor, Malaysia \\ $\underline{\text { sharmini.nicholas@gmail.com }}^{1}, \underline{\text { hazwan@upm.edu.my }}^{2}, \underline{\text { habibahjalil@upm.edu.my }}^{3}$
}

Article History: Received: 11 January 2021; Accepted: 27 February 2021; Published online: 5 April 2021

\begin{abstract}
Organizations that use e-learning as a tool to educate their employees have either reaped the benefits or struggled with its implementation. The dominant reason for this is corporate e-learning overlaps the organizational, human, and technological aspects of learning. Previous research has compartmentalized the research by studying these three aspects separately, so there is little insight on how these variables affect corporate e-learning. Therefore, this study aimed to assess the levels and differences of organizational learning, e-learning quality, and e-learning use according to the demographic groups of corporate e-learners in a Malaysian oil and gas company. A quantitative survey method was applied to collect data from 261 participants using a 5-point Likert Scale questionnaire. The results revealed the level of overall organizational learning, elearning quality, and e-learning use was moderate. Furthermore, organizational learning, e-learning quality, and e-learning use were significantly different for gender, department, and job position demographic groups. However, age and working experience did not show a significant difference for these variables. The findings from this study provide a bottom-up insight to stakeholders and managers when investing in and implementing e-learning at the organization.
\end{abstract}

Keywords: Organizational Learning Model, corporate e-learning, e-learning quality, e-learning use, IS Success Model,organizational learning.

\section{Introduction}

The integration of technology in the workplace has evolved workplace learning in many different ways. It has evolved from structured training programs to modern technology-enhanced workplace learning, which happens through the flow of work, on-demand, short pulses, and constant. While acknowledged as necessary for any organization to stay competitive, learning at the workplace is not expected to interrupt the work routine but to merge seamlessly into it because the main purpose of businesses is to generate revenue (Migdadi, 2019). This is where learning technologies facilitate the workplace learning process by enabling the learner to be an active participant rather than a mere observer(Ifenthaler,2018). Learners have to use pockets of time that become spontaneously available during their work to engage in learning activities (Tvenge\&Martinsen, 2018). The unstructured learning schedule of corporate employees makes it hard to synchronize learning activities with other people, such as classroom training. However, with learning technology modules that are short, flexible, and created to be accomplished unsynchronized, it becomes possible for learners to embrace modern workplace learning (Gronseth\& Hutchins, 2020; Littlejohn \&Margaryan, 2014).

Workplace learning technologies come in many different forms. For instance, web tools such as e-learning, video conferencing, social and professional e-networks, instant messaging, and file sharing are among the most popular tools that support corporate learning (Hester \& Hutchins,2016). In many ways, the use of technology for learning at the workplace yields positive results. It enables learners to access quality information on demand, facilitates collaboration amongst colleagues in multi-location offices, increases capabilities while simultaneously decreasing costs, and extends information access beyond the boundaries of the organization (Li \& Herd, 2017; Colbert et al., 2016; Haas et al., 2014).

These benefits have motivated organizations to use e-learning as a tool to educate their employees. Research has shown that organizations that excel at implementing corporate e-learning experience improvements in employee efficiency, productivity, lifelong learning, and morale boost. These improvements have been known to pave the way for long-term organizational success (Gabelaia\&Bucovetchi, 2020; Seufert \& Meier,2016). In contrast, organizations that struggle with e-learning experience difficulty tracking e-learners' progress, matching the course design to suit the different learning styles, acquiring appropriate technological infrastructure, and resistance from e-learners (Vančová\&Kovačičová,2018).

These contrasting experiences from organizations are unsurprising as corporate e-learning intersects between the organizational, human, and technological aspects of learning. Hence, providing high-quality elearning material alone is not enough to guarantee the usage of e-learning. The organizational learning environment in which the e-learning takes place also influences e-learning in the organization (Kapo et al., 2020; Schaefer et al., 2019; Schaefer et al., 2018).Studies have also revealed that human factors, i.e. demographic factors, also shape the e-learning environment. However, these studies have focused on the education sector (Wongwatkit et al., 2020; Tarhini et al., 2016; Islam, 2011). Consequently, there is scarce information on 
demographic factors of corporate e-learning and organizational learning in the literature. Therefore, this research aims to:

1. Identify the levels of organizational learning, e-learning quality, and e-learning use among corporate elearners of a Malaysian company.

2. Investigate the differences in organizational learning, e-learning quality, and e-learning use according to demographic groupsof the corporate e-learners.

\section{Literature Review}

\subsection{Corporate E-learningandIts Evolution}

E-learning is "any type of learning, teaching or educational activity, which is based on computer and internet technologies" (Fallon \& Brown, 2003, p. 4). Corporate e-learning is usually packaged as a Learning Management System (LMS) and has continued to evolve and grow as new trends emerge in the e-learning landscape (Bezhovski\&Poorani,2016). It has been a popular tool for organizational learning since the early 2000's due to its two-fold benefits for employers and employees. For employers, e-learning is appealing because it is flexible, easily accessible, scalable, cost-effective, and tailored to the corporation's needs(Chen, 2008). For employees, e-learning offers an engaging learning experience at their own pace of learning, style, and convenience (Lenoue et al., 2011).

There are a few key differences between corporate e-learning and academic e-learning (Prakash,2018; Chang, 2016). Firstly, academic e-learning focuses on a broad scope to accomplish personal learning goals, whereas corporate e-learning is specific to business needs. Secondly, individual characteristics are one of the main drivers for successfully implementing e-learning in the academic sector. In contrast, organizational characteristics play an important role in corporate e-learning. Lastly, to keep up with new products, services, and market conditions, e-learning in the corporate sector tends to evolve faster than e-learning in the academic sector.

Corporate e-learning has continued to evolve alongside technological advancements to create and deliver learning through various mediums. During the 1990s, CD-ROMs were considered the most popular medium for delivering e-learning content because they were cheap and easy to use. In the early 2000s, increased internet access and personal computer use enabled organizations to deliver computer-based training (CBT) over a network. As the internet and the World Wide Web have transitioned from Web 0.0 to Web 4.0, e-learning has also evolved from static, read-only modules to interactive and intelligent systems (Choudhury \&Pattnaik, 2020). Fig. 1 below shows the evolution of corporate e-learning over30 years starting from the 1990s.

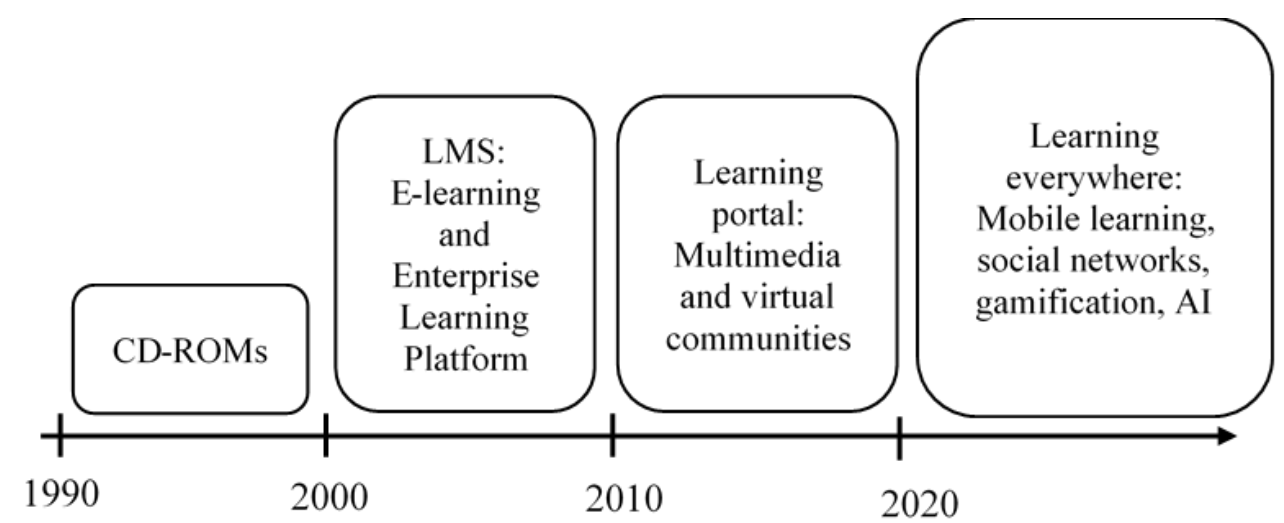

Fig.1. Evolution of corporate e-learning - summarized from Haikonen (2016).

\subsection{E-learningQualityand Use Basedonthe Information System Success Model}

Over the years, researchers have proposed different models and theories to explain the relations between technology and users' behavior. One of the most extensively used models is the Information System Success Model (IS Success Model). The IS Success Model developed by DeLone and McLean (1992) clarifies the human and technological aspects of information systems. The first version of the model had six dimensions: system quality, information quality, use, user satisfaction, individual impact, and organizational impact. The updated model, DeLone and McLean (2003), shown in Fig.2, combined individual and organizational benefits into net benefits. It also added service quality as another dimension to represent the role of service providers such as the IT department of an organization.This model has been used widely, partially or completely, in e-learning research (Bento et al., 2017). 


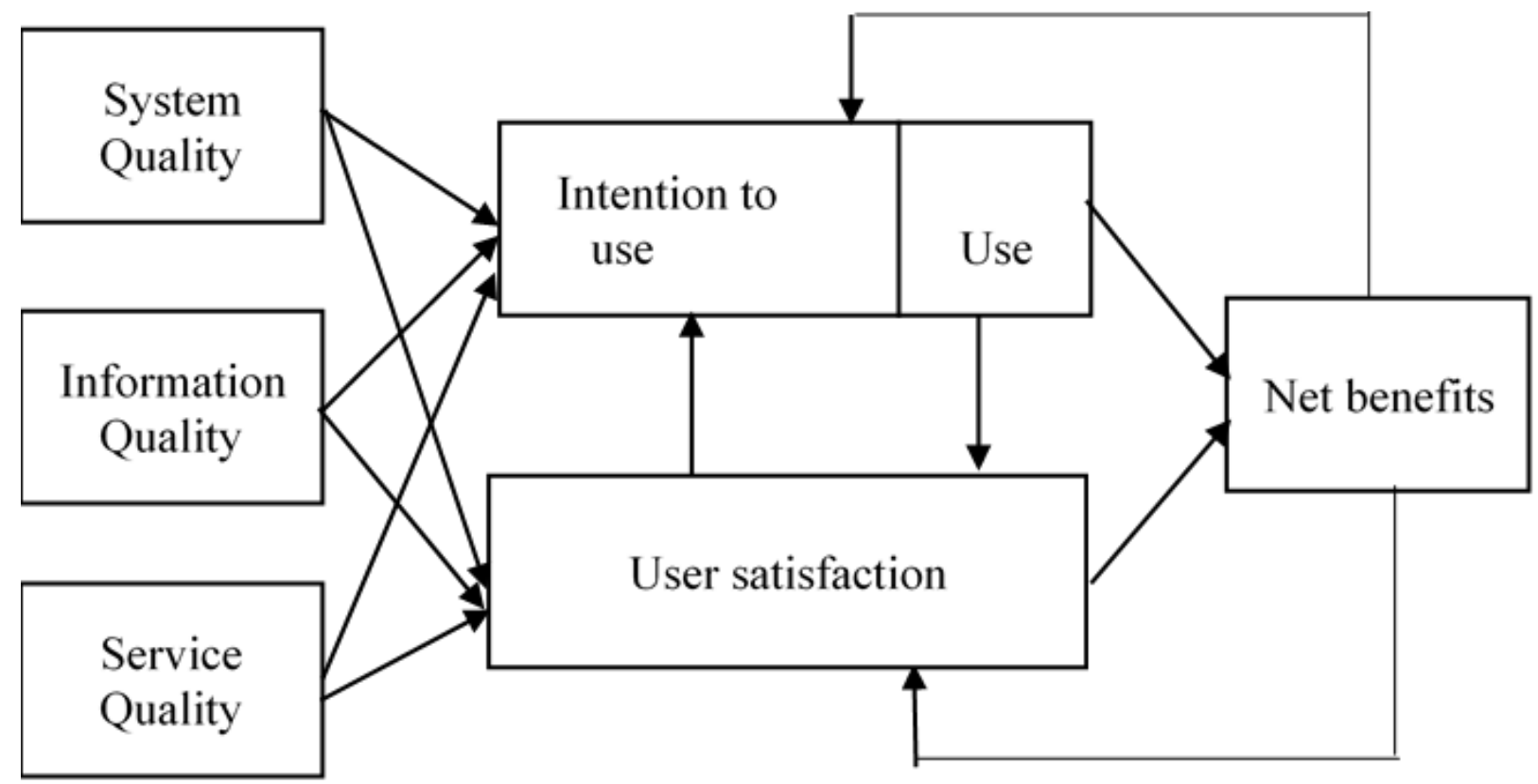

Fig.2. The DeLone and McLean's updated IS Success Model (p. 24) [29]

Additionally, the model proposed intention to use as an alternative to use in certain contexts but stressed that intention to use is an attitude while use is a behavior. Use is embedded in a feedback loop with user satisfaction and net benefits, which leads to subsequent use. This study emphasizes the quality and uses aspects of the IS Success Model because, with the increasing demands in the industry and the sophisticated advances of technology, e-learning providers are expected to provide high-quality e-learning to users.

System quality, information quality, and service quality are desirable characteristics that facilitate the successful implementation of an e-learning system in an organization.DeLone\& McLean (2016, p. 11) defined each category as follows:

(i) System quality is the technical characteristics of the system, including its reliability, flexibility, and ease of use.

(ii) Information quality is the content of the system that includes accuracy, conciseness, relevance, and completeness.

(iii) Service quality is the support that system users receive from the IT department or personnel, including responsiveness, reliability, and technical competence.

There is consensus in the literature that these three components make up the overall quality aspects of an elearning system (Aldholay et al., 2018; Isaac et al., 2017).For e-learning systems that have already been established in an organization and where usage is voluntary, e-learning use has been considered a suitable measure of e-learning success.E-learning use refers to the degree and manner in which corporate e-learners utilize the capabilities of the e-learning system (DeLone\& McLean, 2016, p. 11). It includes the amount of use, frequency of use, nature of use, and extent of use by its users in the company.

\subsection{Organizational Learning Environmentin Corporate E-learning}

Workplace e-learning must be driven by organizational learning (Montgomerie et al., 2016; Yang, 2019). This is because when employees are engaged in corporate e-learning, they are involved in achieving organizational learning goals as well as individual learning goals. Organizational learning is a dynamic process of integrating new learning and using what has already been learned across the individual, group, and organization levels (Crossan et al., 1999). These three levels of organizational learning are linked by four broad categories of social and psychological processes: intuiting, interpreting, integrating, and institutionalizing (4Is), in Crossan et al.'s 4I Organizational Learning Model, shown in Fig.3. 


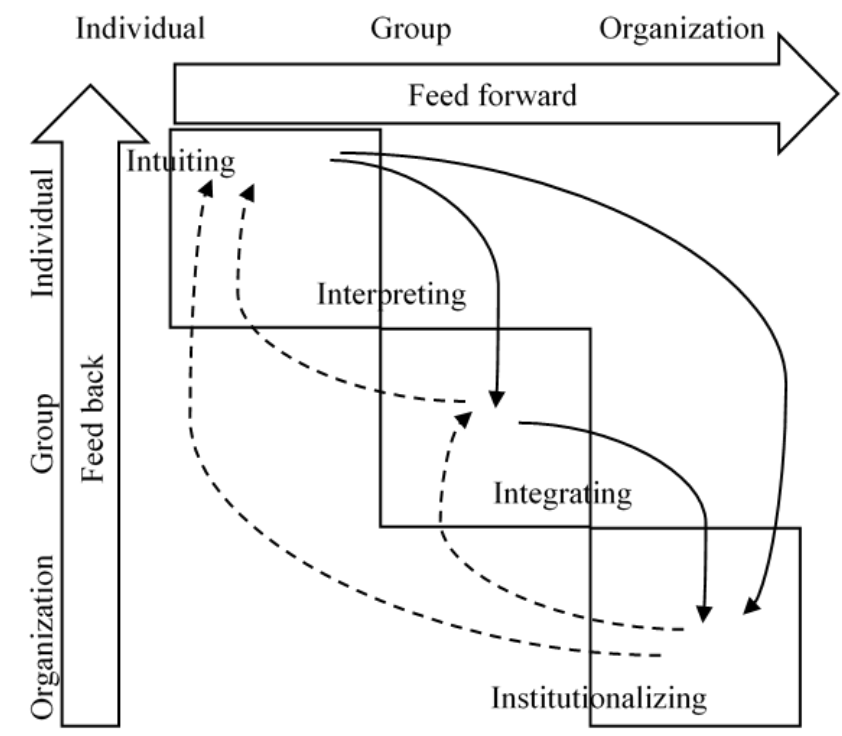

Fig.3. 4I Organizational Learning Model (Crossan et al., 1999, p. 532)

Organizational learning happens when individuals receive information, transform it into knowledge, and spread the knowledge throughout the organization(Bontis et al., 2002).Bontis et al. (2002, p.443) define the three levels as follows:

(i) Individual learning level refers to "individual competence, capability, and motivation to undertake the required tasks."

(ii) Group learning level is the "group dynamics and the development of shared understanding."

(iii) Organization learning level is the "alignment between the non-human storehouses of learning including systems, structure, strategy, procedures, and culture, given the competitive environment."

Researchers agree that organizational learning is not merely a sum of individual learning of the organization's members, but rather, it occurs due to the interaction between the three levels (Oltra et al., 2018). Thus, individual, group and organization learning levels are components of overall organizational learning(Aragón et al., 2014). Furthermore, the organization's learning environment is perceived as either an enabler or barrier to e-learning participation (Garavan et al., 2010).

\subsection{Demographic Factors}

Gender refers to the cultural connotations given to male and female social categories in social institutions and practices (Wood \&Eagly, 2009). Previous research has found that men and women vary in socially constructed cognitive structures, problem-solving skills, and decision-making processes (Nagahi et al., 2019; Venkatesh\&Morris, 2000). This difference has been observed in the higher education e-learning sector, where male and female students showed different perceptions of their e-learning environment and usage behavior. Female students tended to be driven by positive emotions, whereas male students were more influenced by the functional and practical aspects of their e-learning environment(Wongwatkit et al., 2020). In contrast to this, other studies have also found no significant differences between the genders regarding their perception of elearning (Khechine et al., 2014; Al-Gahtani et al., 2007).

Although age is an important demographic in e-learning studies, the results from prior research show contrasting findings. Some studies found that younger adults fared better with e-learning systems as compared to older adults(Khechine et al., 2014; Venkatesh et al., 2003). However, other studies challenge this stereotype by claiming that age per se does not significantly influence users' behavior and perception of e-learning systems. Rather, in older adults, other intervening factors such as confidence, self-efficacy, perceived ease of use, and a supportive environment matter(Guner\&Acarturk, 2018; Hauk et al, 2018; Chu, 2010).

Organizations are usually made up of various departments, depending on their business model and size. Each department has specific job functions, which result in differentiated training programs. For example, the training for clerical and support staff focused on the broad overview of how the company worked as well as specialist skills. In contrast, the training for technical staff was highly technical and lasted for a few years (Ashton, 2004). In the context of e-learning, e-learning modules' relevance for the specific tasks influences employees' perception and usage behavior(Vančová\&Kovačičová, 2018).

The concept of working experience refers to the experience an employee gains from being employed in a specific field or occupation. In the context of corporate e-learning, the longer an employee is employed, the more experience is also gained in e-learning. Research has found that the degree of an individual's experience determines the level of perception and usage behavior towards an e-learning system where expert users performed better than novice users (Venkatesh\&Bala, 2008; Kim, 2008). Furthermore, unlike junior employees, senior employees tended to form supportive learning networks to boost their workplace learning (Ashton, 2004). 
Job positions according to power-based hierarchy are a common feature in organizations (van Kleef\& Cheng, 2020). Although the hierarchical culture establishes clear lines of authority and responsibilities in an organization, it has been found to inhibit individual learning(Oh \& Han,2018). Studies have found uneven access to learning between management and non-management positions. Managerial positions have more control over the distribution and access to knowledge than non-managerial positions (Ashton, 2004).

\section{Methodology}

This descriptive and quantitative study was conducted in a multinational Malaysian oil and gas company. The oil and gas industry was selected as the study population because it is an industry that requires highly trained employees and has a strong culture of state-of-the-art learning and development programs for its employees. The Sarawak branch was chosen over other locations because of the researchers' convenience and accessto the study location. The data collection for this research was carried out via a quantitative survey. The researchers utilized valid and reliable instruments from previous studies for the data collection(Check \& Schutt, 2012). The questionnaire was the most effective way to collect data from the large number of participants involved. The questionnaires were administered through selected employees who acted as intermediaries between the researcher and the respondents. This study uses a centralized e-learning program that is disseminated from its headquarters to ensure that the system is standardized across its different branches. The questionnaire was adapted from the E-learning Success System (ELSS) instrument by Wang et al. (2007) and the Strategic Learning Assessment Map (SLAM) instrument by Bontis et al.(2002). The questionnaire was divided into four sections: Section A covered demographic data, Section B covered e-learning quality, Section C covered organizational learning, and Section D covered e-learning use. The participants were asked to self-evaluate a list of statements based on a Likert's five-point scale ranging from (1) strongly disagree to (5) strongly agree. The Likert scale is well-established and widely used in the survey method (Lavrakas , 2008). The reliability of the questionnaire used in this study was $\alpha=0.852$, which is considered good (George \& Mallery, 2016).

Participants of this study were either male or female employees above 18 years that used e-learning for work. These individuals used e-learning for their personal development and to achieve the company's goals. A total of 261 respondents participated in this study via the convenience sampling method. The extended data collection period that spanned from January 2020 to September 2020 is responsible for the $100 \%$ response rate. During this time, repeated attempts were made to get the questionnaires completed. It was not feasible to implement a randomized selection of participants in the company due to the unwillingness or unavailability of the participants and bureaucratic red tape. The convenience sampling was considered suitable by the intermediaries' accessibility to the respondents (Bryman, 2016).Even though a non-probability sampling method was used, because e-learning is implemented throughout the company, it was assumed that there would not be a significant difference between a randomly selected and a conveniently selected sample (Etikan et al., 2016).

In order to determine the levels of organizational learning, e-learning quality, and e-learning use among the e-learners at the research site, the mean scores were categorized into three levels: low, moderate, and high. This procedure was performed with IBM SPSS Statistics using quartiles to determine the levels as illustrated in Fig.4(Wagner, 2019).

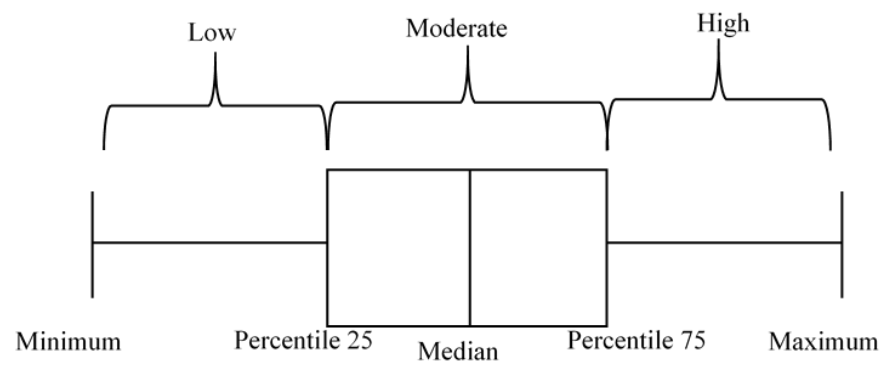

Fig.4. Quartiles of the mean scores

Mean scores below percentile 25 (< percentile 25) were considered low, while mean scores between percentile 25 to below 75 ( $\geq$ percentile 25 and $<$ percentile 75 ) were classified as moderate. Means scores above percentile 75 ( $\geq$ percentile 75 ) were considered high. The level of the variables was interpreted by using the quartiles of the mean scores, as presented in Table 1.

Table 1. Interpretation of mean scores

\begin{tabular}{|l|l|l|l|}
\hline Mean Scores & \multirow{2}{*}{ Level } \\
\hline Organizational learning & E-learning quality & E-learning use & \\
\hline$\leq 3.04$ & $\leq 3.12$ & $\leq 2.79$ & Low \\
\hline $3.05-3.99$ & $3.13-3.91$ & $2.80-3.59$ & Moderate \\
\hline$\geq 4.00$ & $\geq 3.92$ & $\geq 3.60$ & High \\
\hline
\end{tabular}


The differences with the demographic factors for organizational learning, e-learning quality, and e-learning use in this study were analyzed using Independent Samples t-test and One-way Analysis of Variance (ANOVA). T-test was used to evaluate if there was a statistically significant difference between the means in two independent groups. One-way ANOVA was used to verify whether there were any statistically significant differences between the means of two or more independent groups. In this study, a t-test was used for gender, department, and job position, while one-way ANOVA was used for age and working experience. A p-value of less than $0.05(\mathrm{p}<0.05)$ indicatedwhen the mean differences were significant.

\section{Data Analysis and Results}

\subsection{Demography of Respondents}

The data for the participants' demography were analyzed using frequency and percentage. The results are shown in Table 2.Five demographic categories were queried in the questionnaire, i.e., gender, age, department, working experience, and job position. In this study, the majority of the participants were male $(61.7 \%)$, between $30-55$ years old $(61.7 \%)$, belonged to a technical department $(93.9 \%)$, had $1-10$ years working experience $(66.3 \%)$, and belonged to a non-management job position $(81.6 \%)$.

Table 2. Demographic Profile of Respondents

\begin{tabular}{|c|c|c|c|}
\hline \multicolumn{2}{|l|}{ Demography } & Frequency & Percentage $(\%)$ \\
\hline \multirow[t]{2}{*}{ Gender } & Male & 161 & 61.7 \\
\hline & Female & 100 & 38.3 \\
\hline \multirow[t]{3}{*}{ Age } & $18-29$ years old & 82 & 31.4 \\
\hline & $30-55$ years old & 161 & 61.7 \\
\hline & $>55$ years old & 18 & 6.9 \\
\hline \multirow[t]{2}{*}{ Department } & Technical & 245 & 93.9 \\
\hline & Non-technical & 16 & 6.1 \\
\hline \multirow{4}{*}{$\begin{array}{l}\text { Working experience } \\
\text { (years) }\end{array}$} & $1-10$ & 173 & 66.3 \\
\hline & $11-20$ & 77 & 29.5 \\
\hline & $21-30$ & 9 & 3.4 \\
\hline & $>30$ & 2 & 0.8 \\
\hline \multirow[t]{2}{*}{ Job position } & Management & 48 & 18.4 \\
\hline & Non-management & 213 & 81.6 \\
\hline
\end{tabular}

\subsection{Overall Level of Organizational Learning, E-Learning Quality, and E-Learning Use}

The level ofoverallorganizational learning was moderate $(\mathrm{M}=3.50, \mathrm{SD}=0.61)$, which indicates that the participants acknowledged the company's conducive learning culture.The level of overall e-learning quality was moderate $(\mathrm{M}=3.53, \mathrm{SD}=0.58)$, which indicates that, on average, the participants agreed that the company had a satisfactory e-learning system. The level of e-learning use was moderate $(\mathrm{M}=3.22, \mathrm{SD}=0.70)$, which indicates that participants generally used the e-learning system at work. Table 3 summarisesthe items and the results for the level of organizational learning, e-learning quality and e-learning use.

Table 3. Items andLevel of Organizational Learning, E-Learning Quality, and E-Learning Use

\begin{tabular}{|c|c|c|c|c|}
\hline \multicolumn{2}{|l|}{ Item } & $\begin{array}{l}\text { Mean } \\
(\mathrm{M})\end{array}$ & $\begin{array}{l}\text { Standard } \\
\text { Deviation } \\
\text { (SD) }\end{array}$ & Interpretation \\
\hline \multicolumn{2}{|c|}{ Organizational Learning } & 3.50 & 0.61 & Moderate \\
\hline \multicolumn{5}{|c|}{ Individual Learning Level } \\
\hline IL1 & $\begin{array}{l}\text { I am able to break out of traditional mind-sets to see things in } \\
\text { new and different ways }\end{array}$ & 3.66 & 0.73 & Moderate \\
\hline IL2 & I feel a sense of pride in my work & 3.59 & 0.79 & Moderate \\
\hline IL3 & I have a clear sense of direction in my work & 3.54 & 0.83 & Moderate \\
\hline IL4 & I generate many new insights & 3.53 & 0.74 & Moderate \\
\hline IL5 & I am aware of the critical issues that affect my work & 3.51 & 0.83 & Moderate \\
\hline IL6 & I feel confident in my work & 3.59 & 0.79 & Moderate \\
\hline \multicolumn{2}{|c|}{ Overall } & 3.57 & 0.66 & Moderate \\
\hline \multicolumn{5}{|c|}{ Group Learning Level } \\
\hline GL1 & We have effective conflict resolution when working in groups & 3.52 & 0.78 & Moderate \\
\hline GL2 & Different points of view are encouraged in group work & 3.52 & 0.77 & Moderate \\
\hline GL3 & Groups have the right people involved in addressing the issues & 3.47 & 0.81 & Moderate \\
\hline GL4 & We share our success within the group & 3.52 & 0.78 & Moderate \\
\hline
\end{tabular}




\begin{tabular}{|c|c|c|c|c|}
\hline GL5 & In meetings, we seek to understand everyone's point of view & 3.46 & 0.79 & Moderate \\
\hline GL6 & Groups in the organization are adaptable & 3.45 & 0.76 & Moderate \\
\hline GL7 & $\begin{array}{l}\text { Groups are prepared to rethink decisions when presented with } \\
\text { new information. }\end{array}$ & 3.53 & 0.78 & Moderate \\
\hline \multicolumn{2}{|r|}{ Overall } & 3.50 & 0.65 & Moderate \\
\hline \multicolumn{5}{|c|}{ Organization Learning Level } \\
\hline OL1 & We have a strategy that positions us well for the future & 3.55 & 0.76 & Moderate \\
\hline OL2 & We have the necessary systems to implement our strategy & 3.50 & 0.76 & Moderate \\
\hline OL3 & The organization's culture could be characterized as innovative & 3.44 & 0.77 & Moderate \\
\hline OL4 & The organizational structure allows us to work effectively & 3.43 & 0.79 & Moderate \\
\hline OL5 & We have a realistic yet challenging vision for the organization & 3.45 & 0.77 & Moderate \\
\hline OL6 & $\begin{array}{l}\text { We have an organizational culture characterized by a high } \\
\text { degree of trust }\end{array}$ & 3.39 & 0.80 & Moderate \\
\hline OL7 & Our operational procedures allow us to work efficiently & 3.43 & 0.79 & Moderate \\
\hline \multicolumn{2}{|c|}{ Overall } & 3.46 & 0.66 & Moderate \\
\hline \multicolumn{2}{|c|}{ E-learning Quality } & 3.53 & 0.58 & Moderate \\
\hline \multicolumn{5}{|c|}{ Information Quality } \\
\hline IQ1 & The e-learning system provides correct information & 3.80 & 0.73 & Moderate \\
\hline IQ2 & The e-learning system provides accurate information & 3.75 & 0.77 & Moderate \\
\hline IQ3 & The e-learning system provides complete information & 3.60 & 0.77 & Moderate \\
\hline IQ4 & The e-learning system provides sufficient information & 3.54 & 0.81 & Moderate \\
\hline IQ5 & The e-learning system provides precise information & 3.57 & 0.77 & Moderate \\
\hline IQ6 & The e-learning system provides clear information & 3.67 & 0.76 & Moderate \\
\hline IQ7 & $\begin{array}{l}\text { The information provided by the e-learning system meets my } \\
\text { needs }\end{array}$ & 3.59 & 0.80 & Moderate \\
\hline IQ8 & $\begin{array}{l}\text { The information provided by the e-learning system helps to } \\
\text { solve my problems }\end{array}$ & 3.48 & 0.83 & Moderate \\
\hline \multicolumn{2}{|r|}{ Overall } & 3.63 & 0.63 & Moderate \\
\hline \multirow{2}{*}{\multicolumn{5}{|c|}{ System Quality }} \\
\hline & & & & \\
\hline SYQ1 & The e-learning system provides good interaction mechanisms & 3.59 & 0.89 & Moderate \\
\hline SYQ2 & $\begin{array}{l}\text { The buttons for the operation of the e-learning system can be } \\
\text { clearly understood }\end{array}$ & 3.71 & 0.79 & Moderate \\
\hline SYQ3 & $\begin{array}{l}\text { The buttons for the operation of the e-learning system can be } \\
\text { easily understood }\end{array}$ & 3.75 & 0.75 & Moderate \\
\hline SYQ4 & The e-learning system responds quickly & 3.72 & 0.75 & Moderate \\
\hline SYQ5 & The e-learning system is seldom out of use & 3.49 & 0.79 & Moderate \\
\hline SYQ6 & The functions of the e-learning system work well & 3.67 & 0.78 & Moderate \\
\hline \multicolumn{2}{|c|}{ Overall } & 3.66 & 0.63 & Moderate \\
\hline \multirow{2}{*}{\multicolumn{5}{|c|}{ Service Quality }} \\
\hline & & & & \\
\hline SVQ1 & $\begin{array}{l}\text { The e-learning system provides a proper level of online } \\
\text { assistance }\end{array}$ & 3.36 & 0.81 & Moderate \\
\hline SVQ2 & $\begin{array}{l}\text { The e-learning system provides a proper level of online } \\
\text { explanation }\end{array}$ & 3.33 & 0.78 & Moderate \\
\hline SVQ3 & $\begin{array}{l}\text { The IT department staff provides high availability for } \\
\text { consultation }\end{array}$ & 3.17 & 0.83 & Moderate \\
\hline SVQ4 & $\begin{array}{l}\text { The IT department responds in a cooperative manner to my } \\
\text { suggestion for future enhancements of the e-learning system }\end{array}$ & 3.11 & 0.83 & Low \\
\hline $\begin{array}{l}\text { SVQ5 } \\
\end{array}$ & $\begin{array}{l}\text { The IT department provides satisfactory support to users using } \\
\text { the e-learning system }\end{array}$ & 3.20 & 0.84 & Moderate \\
\hline \multicolumn{2}{|c|}{ Overall } & 3.24 & 0.70 & Moderate \\
\hline \multicolumn{2}{|c|}{ E-learning Use } & 3.22 & 0.70 & Moderate \\
\hline EU1 & Frequency do you use the e-learning system & 3.08 & 0.96 & Moderate \\
\hline EU2 & $\begin{array}{l}\text { Functions of the e-learning system (e.g. videos, slides, } \\
\text { assessments) }\end{array}$ & 3.38 & 0.91 & Moderate \\
\hline EU3 & I depend on the e-learning system when other types of training & 3.16 & 0.79 & Moderate \\
\hline
\end{tabular}


Demographic Factors of Corporate E-learning among E-learners in an Oil and Gas Company

\begin{tabular}{|l|l|l|l|l|}
\hline & are not available & & & \\
\hline EU4 & I use the e-learning system in addition to other types of training. & 3.04 & 0.86 & Moderate \\
\hline EU5 & The e-learning system usage is voluntary & 3.46 & 0.97 & Moderate \\
\hline
\end{tabular}

\subsection{Organizational Learning, E-Learning Quality, and E-Learning Use According to Demographic Group}

Table 4 summarises the level and differences of organizational learning, e-learning quality and e-learning use according to the demographic groups in this study.

Table 4. Level and differences of organizational learning, e-learning quality and e-learning use according to the demographic groups

\begin{tabular}{|c|c|c|c|c|c|}
\hline \multirow{14}{*}{$\begin{array}{l}\text { Variable } \\
\text { Organizational } \\
\text { learning }\end{array}$} & \multicolumn{2}{|l|}{ Demography } & Mean & \multirow{3}{*}{$\begin{array}{l}\mathbf{t , d f} / \mathbf{F}, \mathbf{d f} \\
2.00,259\end{array}$} & \multirow{3}{*}{$\begin{array}{l}\text { p-value } \\
* .04\end{array}$} \\
\hline & \multirow[t]{2}{*}{ Gender } & Male & $3.56_{M}$ & & \\
\hline & & Female & $3.41_{\mathrm{M}}$ & & \\
\hline & \multirow[t]{3}{*}{ Age } & $18-29$ & $3.45_{\mathrm{M}}$ & \multirow[t]{3}{*}{$0.56,258$} & \multirow[t]{3}{*}{.57} \\
\hline & & $30-55$ & $3.54_{M}$ & & \\
\hline & & $>55$ & $3.48_{\mathrm{M}}$ & & \\
\hline & \multirow[t]{2}{*}{ Department } & Non-technical & $3.77_{M}$ & \multirow[t]{2}{*}{$1.79,259$} & \multirow[t]{2}{*}{.07} \\
\hline & & Technical & $3.49_{\mathrm{M}}$ & & \\
\hline & \multirow{4}{*}{ Working Experience } & $1-10$ & $3.47_{\mathrm{M}}$ & \multirow[t]{4}{*}{$0.79,257$} & \multirow[t]{4}{*}{.50} \\
\hline & & $11-20$ & $3.57_{\mathrm{M}}$ & & \\
\hline & & $21-30$ & $3.59_{\mathrm{M}}$ & & \\
\hline & & $>30$ & $3.85_{M}$ & & \\
\hline & \multirow[t]{2}{*}{ Job Position } & Management & $3.74_{M}$ & \multirow[t]{2}{*}{$3.05,259$} & \multirow[t]{2}{*}{$* .01$} \\
\hline & & Non-management & $3.45_{\mathrm{M}}$ & & \\
\hline \multirow{13}{*}{$\begin{array}{l}\text { E-learning } \\
\text { quality }\end{array}$} & \multirow[t]{2}{*}{ Gender } & Male & $3.56_{\mathrm{M}}$ & \multirow[t]{2}{*}{$0.87,259$} & \multirow[t]{2}{*}{.38} \\
\hline & & Female & $3.49_{\mathrm{M}}$ & & \\
\hline & \multirow[t]{3}{*}{ Age } & $18-29$ & $3.48_{\mathrm{M}}$ & \multirow[t]{3}{*}{$0.50,258$} & \multirow[t]{3}{*}{.60} \\
\hline & & $30-55$ & $3.56_{\mathrm{M}}$ & & \\
\hline & & $>55$ & $3.57_{M}$ & & \\
\hline & \multirow[t]{2}{*}{ Department } & Non-technical & $3.87_{M}$ & \multirow[t]{2}{*}{$2.39,259$} & *.01 \\
\hline & & Technical & $3.51_{\mathrm{M}}$ & & \\
\hline & Working Experience & $1-10$ & $3.50_{\mathrm{M}}$ & $0.75,257$ & .52 \\
\hline & & $11-20$ & $3.59_{\mathrm{M}}$ & & \\
\hline & & $21-30$ & 3.71 $1_{M}$ & & \\
\hline & & $>30$ & $3.26_{\mathrm{M}}$ & & \\
\hline & Job Position & Management & $3.73_{M}$ & $2.66,259$ & *.01 \\
\hline & & Non-management & $3.49_{\mathrm{M}}$ & & \\
\hline E-learning use & Gender & Male & $3.24_{M}$ & $0.52,259$ & .59 \\
\hline & & Female & $3.20_{\mathrm{M}}$ & & \\
\hline & Age & $18-29$ & $3.24_{\mathrm{M}}$ & $0.18,258$ & .83 \\
\hline & & $30-55$ & $3.21_{M}$ & & \\
\hline & & $>55$ & 3.30M & & \\
\hline & Department & Non-technical & $3.75_{\mathrm{H}}$ & $3.12,259$ & $* .01$ \\
\hline & & Technical & $3.19_{\mathrm{M}}$ & & \\
\hline & Working Experience & $1-10$ & $3.22_{\mathrm{M}}$ & $0.56,257$ & .63 \\
\hline & & $11-20$ & $3.21_{\mathrm{M}}$ & & \\
\hline & & $21-30$ & $3.47_{\mathrm{M}}$ & & \\
\hline & & $>30$ & $3.60_{\mathrm{H}}$ & & \\
\hline & Job Position & Management & $3.40_{\mathrm{M}}$ & $1.86,259$ & .06 \\
\hline & & Non-management & $3.19_{\mathrm{M}}$ & & \\
\hline
\end{tabular}

Key: Highest mean in bold; Levels = L (Low), M (Moderate), $\mathrm{H}$ (High)

Note: $95 \%$ confidence level, * $\operatorname{sig}(\mathrm{p}<0.05)$

\subsubsection{According to Gender}

Table 4 shows that the level of organizational learning, e-learning quality, and e-learning use were moderate for both male and female participants. There were 161 male and 100 female participants. The males had significantly higher levels of organizational learning $(\mathrm{M}=3.56, \mathrm{SD}=0.61)$ compared to females $(\mathrm{M}=3.41$, $\mathrm{SD}=0.60), \mathrm{t}(259)=2.00, \mathrm{p}=.04$. There was no significant difference for e-learning quality, $\mathrm{t}(259)=0.87, \mathrm{p}=$ .38 , and e-learning use, $\mathrm{t}(259)=0.52, \mathrm{p}=.59$, despite men $\left(\mathrm{M}_{\mathrm{EQ}}=3.56, \mathrm{SD}_{\mathrm{EQ}}=0.59 ; \mathrm{M}_{\mathrm{EU}}=3.24, \mathrm{SD}_{\mathrm{EU}}=0.65\right)$ achieving higher scores than women $\left(\mathrm{M}_{\mathrm{EQ}}=3.49, \mathrm{SD}_{\mathrm{EQ}}=0.56 ; \mathrm{M}_{\mathrm{EU}}=3.20, \mathrm{SD}_{\mathrm{EU}}=0.77\right)$. 


\subsubsection{According to Age}

Table 4shows that the level of organizational learning, e-learning quality, and e-learning use was moderate across all the age groups.Participants aged between 30 and 55 years constituted the largest age group in this study. This age group had the highest level of organizational learning $(\mathrm{M}=3.54, \mathrm{SD}=0.64)$ while the $18-29$ age group with 82 participants had the lowest level of organizational learning $(\mathrm{M}=3.45, \mathrm{SD}=0.54)$. The $>55$ age group with 18 participants had the highest level of e-learning quality $(\mathrm{M}=3.57, \mathrm{SD}=0.61)$, whereas the $18-29$ age group had the lowest level of e-learning quality $(\mathrm{M}=3.48, \mathrm{SD}=0.54)$. The $>55$ age group also had the highest level of e-learning use $(\mathrm{M}=3.30, \mathrm{SD}=0.88)$, while the $30-55$ age group had the lowest level of e-learning use $(\mathrm{M}=3.21, \mathrm{SD}=0.69)$. However, despite the different levels between the three age groups, there was no significant difference on organizational learning, $\mathrm{F}(2,258)=0.56, \mathrm{p}=.57$, e-learning quality, $\mathrm{F}(2,258)=0.50, \mathrm{p}=.60$ and e-learning quality, $\mathrm{F}(2,258)=0.18, \mathrm{p}=.83$.

\subsubsection{According to Department}

Table 4 shows that the levels of organizational learning and e-learning quality were moderate for participants from both the non-technical and technical departments. However, the level of e-learning use was high for participants from the non-technical departments and moderated for participants from the technical departments. There was no significant difference for organizational learning, $\mathrm{t}(259)=1.79, \mathrm{p}=.07$, although the non-technical department $(\mathrm{M}=3.77, \mathrm{SD}=0.43)$ scored higher than the technical department $(\mathrm{M}=3.49, \mathrm{SD}=0.62)$. There was a significant difference for e-learning quality, $\mathrm{t}(259)=2.39, \mathrm{p}=.01$, and e-learning use, $\mathrm{t}(259)=3.12$, $\mathrm{p}=.00$,for the non-technical department $\left(\mathrm{M}_{\mathrm{EQ}}=3.87, \mathrm{SD}_{\mathrm{EQ}}=0.45 ; \mathrm{M}_{\mathrm{EU}}=3.75, \mathrm{SD}_{\mathrm{EU}}=0.62\right)$ compared to the technical department participants $\left(\mathrm{M}_{\mathrm{EQ}}=3.51, \mathrm{SD}_{\mathrm{EQ}}=0.59 ; \mathrm{M}_{\mathrm{EU}}=3.19, \mathrm{SD}_{\mathrm{EU}}=0.70\right)$.

\subsubsection{According to Working Experience}

Table 4shows that the levels of organizational learning and e-learning quality were moderate across all the working years of the participants. The level of e-learning use was high for participants who had been working for more than thirty years and moderate for participants who had been working for less than 30 years. Although there were only two e-learners who had worked for more than 30 years, they had the highest level of organizational learning and e-learning use $\left(\mathrm{M}_{\mathrm{OL}}=3.85, \mathrm{SD}_{\mathrm{OL}}=0.21 ; \mathrm{M}_{\mathrm{EU}}=3.60, \mathrm{SD}_{\mathrm{EU}}=0.84\right)$ but the lowest level of e-learning quality $(\mathrm{M}=3.26, \mathrm{SD}=0.52)$. The nine e-learners who had worked between 21 and 30 years had the highest level of e-learning quality $(\mathrm{M}=3.71, \mathrm{SD}=0.72)$. The 173 participants who had worked between 1 and 10 years had the lowest level of organizational learning $(\mathrm{M}=3.47, \mathrm{SD}=0.60)$, while the 77 participants who had worked for 11 20 years had the lowest level of e-learning use $(\mathrm{M}=3.21, \mathrm{SD}=0.61)$. However, despite the different levels between the four working experience groups, there was no significant difference on organizational learning, $\mathrm{F}(3$, $257)=0.79, \mathrm{p}=.50$, e-learning quality, $\mathrm{F}(3,257)=0.75, \mathrm{p}=.52$ and e-learning use $\mathrm{F}(3,257)=0.56, \mathrm{p}=.63$.

\subsubsection{According to Job Position}

Table 4shows that the levels of organizational learning, e-learning quality and e-learning use was moderate for both management and non-management job positions. There was a significant difference for organizational learning, $\mathrm{t}(259)=3.05, \mathrm{p}=.00$, and e-learning quality, $\mathrm{t}(259)=2.66, \mathrm{p}=.00$, for participants in management positions $\left(\mathrm{M}_{\mathrm{OL}}=3.74, \mathrm{SD} \mathrm{DL}_{1}=0.58 ; \mathrm{M}_{\mathrm{EQ}}=3.73, \mathrm{SD}_{\mathrm{EQ}}=0.56\right)$ compared to non-management positions $\left(\mathrm{M}_{\mathrm{OL}}=3.45\right.$, $\left.\mathrm{SD}_{\mathrm{OL}}=0.61 ; \mathrm{M}_{\mathrm{EQ}}=3.49, \mathrm{SD}_{\mathrm{EQ}}=0.58\right)$. There was no significant difference for e-learning use, $\mathrm{t}(259)=1.86, \mathrm{p}=$ .06 , although management positions $(\mathrm{M}=3.40, \mathrm{SD}=0.67)$ scored higher compared to non-management positions $(\mathrm{M}=3.19, \mathrm{SD}=0.71)$.

\section{Discussion}

Overall, the levels of organizational learning, e-learning quality, and e-learning use were found to be moderate.The moderate levels indicate the employees may not be acquiring the optimum level of learning needed to support individual and organizational growth. There is room for improvement in organizational learning, e-learning quality, and e-learning use by the employees, management, and stakeholders in the organization.

The findings showed an interesting dichotomy with regards to gender. Male e-learners had higher levels than females in organizational learning, e-learning quality, and e-learning use. The high number of male participants in this study compared to female participants is similar to other studies that found the oil and gas industry, in general, is dominated by male workers (Williams et al., 2014).Furthermore, the results also revealed that employees above the age of 30 had higher levels of organizational learning and e-learning quality, while those above the age of 55 had the highest e-learning use compared to younger employees. In terms of working experience, employees who had more than 30 years of working experience had higher levels of organizational learning and e-learning use, while those who had more than 21 years of working experience had the highest level of e-learning quality compared to newer employees. The findings for the age and work experience could be a result of the low turnover rate at the research site. Employees who joined the company tended to stay for a long time and become increasingly integrated with the learning culture. Despite the small number of non-technical elearners who were more administratively inclined, they had higher levels of organizational learning, e-learning quality, and e-learning use compared to e-learners who worked intechnical departments. The findings also showed that e-learners in management positions had higher levels of organizational learning, e-learning quality, 
and e-learning use compared to non-management e-learners. It indicates there are different work requirements and experiences between non-technical and technical, and management and non-management participants.

While males scored higher than females across the board, only organizational learning was significantly different between males and females. The difference between the genders' job requirements and work culture in the region may have contributed to this finding. There was no significant difference for e-learning quality and elearning use. This finding contrasts studies on the gender difference in e-learning that have found male employees are more likely to use e-learning compared to female employees because they are motivated by its perceived usefulness, whereas female employees are more concerned about the ease of using the e-learning system (Goswami \& Dutta, 2016).

There was no significant difference between the age groups for organizational learning, e-learning quality, and e-learning use even though older participants scored higher than younger participants. It may be a common stereotype that younger employees are more technologically savvy and, therefore more likely to use e-learning. However, the results validate previous research that found that employees' age alone is not a determinant for elearning. Instead, it depends on how the organization provides effective e-learning and technical support (Fleminget al., 2017).

Only e-learning quality and e-learning use were significantly different between the non-technical and technical groups. The findings suggest that the non-technical e-learners perceived the e-learning system as more likely to assist them in getting their job done. Technical e-learners, on the other hand, require more hands-on and practical training that may not be fully supported by the current e-learning system. This situation supports prior research, which found a significant relationship between e-learning job relevance and e-learning use (Larsen et al., 2009).

There was no significant difference between the three groups of working experience for organizational learning, e-learning quality, and e-learning use. This finding contradicts prior research, which found that senior employees perform better at e-learning compared to junior employees (Venkatesh\&Bala, 2008; Kim, 2008).

Only organizational learning and e-learning quality were significantly different between the management and non-management participants. It indicates that e-learners in management positions have different insights and perceptions regarding the company's learning culture and e-learning system compared to e-learners in nonmanagement positions, which validate prior research (Ashton, 2004).

\section{Conclusion}

This study investigated the demographic factors of corporate e-learning among e-learners of a Malaysian company. The findings revealed that there was a significant difference in organizational learning between males and females, and management and non-management e-learners. Therefore, gender and job position influence the perspective of the participants about their organization's learning environment. The study also found a significant difference in e-learning quality between non-technical and technical departments and management and non-management e-learners. This finding indicates the work scope and nature of the different departments and job positions impact the participants' view of the e-learning system in the organization. The only significant difference for e-learning use was found between the non-technical and technical departments. This finding suggests that participants in the non-technical department are more likely to use the e-learning systemcompared to the technical department. Finally, in this study, age and working experience did not have a significant difference in organizational learning, e-learning quality, and e-learning use.

\section{Limitation, Recommendation, and Implication}

The findings of the present study are generalizable only to the population at the research site. Therefore, more studies that gather data from multiples sites and sources, for example, from different companies or industries, are recommended. This study also does not consider the relationships between the demographic factors, organizational learning, e-learning quality, and e-learning use. Future studies could investigate how the variables affect each other or build a structural equation model that can be applied to a corporate setting.

By examining organizational learning and e-learning at the individual level, this study provides a bottom-up insight to stakeholders and managers when investing in and implementing e-learning at the organization. The findings suggest that a holistic approach is a key to effective e-learning in the organization.

As there is a significant difference between the genders for organizational learning, the management should reconsider their learning strategies and work culture in order to bridge the gender gap within the organization.

The significant difference between the non-technical and technical departments for e-learning quality and elearning use indicates the company should seriously contemplate ways to make technical training more relevant and accessible to its e-learners as the majority of them belong to the technical line. If most of them perceive that the e-learning system would meet their needs, then the levels of organizational learning, e-learning quality, and e-learning use in the company could increase.

The significant difference in e-learning quality and e-learning use between the management and nonmanagement participants reveals uneven access to learning. The management should strategize and elevate the non-management e-learners' levels of organizational learning, e-learning quality, and e-learning use as they make up the bulk of the company's employees. 


\section{References}

1. Aldholay, A., Isaac, O., Abdullah, Z., \&Ramayah, T. (2018). The role of transformational leadership as a mediating variable in DeLone and McLean information system success model: The context online learning usage in Yemen. Telematics and Informatics, 35(5), 1421-1437. https://doi.org/10.1016/j.tele.2018.03.012

2. Al-Gahtani, S. S., Hubona, G. S., \& Wang, J. (2007). Information technology (IT) in Saudi Arabia: Culture and the acceptance and use of IT. Information and Management, 44 (8), 681-691. http://dx.doi.org/10.1016/j.im.2007.09.002

3. Aragón, M., Jiménez, D., \& Valle, R. (2014). Training and performance: The mediating role of organizational learning. BRQ Business Research Quarterly, 17(3), 161-173. https://doi.org/10.1016/j.cede.2013.05.003

4. Ashton, D. N. (2004). The impact of organisational structure and practices on learning in the workplace. International Journal of Training and Development, 8(1) 43-53. https://doi.org/10.1111/j.13603736.2004.00195.x

5. Bento, F., Costa, C., \& Aparicio, M. (2017, June 21-24). I.S. Success Model, 25 years of evolution [Conference Paper]. 12th Iberian conference on information systems and technologies, Lisbon, Portugal. https://doi.org/10.23919/CISTI.2017.7975884

6. Bezhovski, Z., \& Poorani, S. (2016). The Evolution of E-learning and New Trends. Information and Knowledge Management, 6(3), 50-57.

7. Bontis, N., Crossan, M., \& Hulland, J. (2002). Managing an organizational learning system by aligning stocks and flows. Journal of Management Studies, 39(4), 437-469. https://doi.org/10.1111/14676486.t01-1-00299

8. Bryman, A. (2016). Social research methods (5th ed.). Oxford University Press.

9. Chang, V. (2016). Review and discussion: E-learning for academia and industry. International Journal of Information Management, 36(3), 476-485. https://doi.org/10.1016/j.ijinfomgt.2015.12.007

10. Check, J., \& Schutt, R. (2012). Research methods in education. Sage Publications.

11. Chen, E. T. (2008). Successful e-learning in corporations successful e-learning in corporations. Communications of the IIMA, 8(2), 45-54.

12. Choudhury, S., \& Pattnaik, S. (2020). Emerging themes in e-learning: A review from the stakeholders' perspective. Computers \& Education, 144, 2 - 20. https://doi.org/10.1016/j.compedu.2019.103657

13. Chu, R. (2010). How family support and Internet self-efficacy influence the effects of e-learning among higher aged adults -Analyses of gender and age differences. Computers \& Education, 55(1), 255-264, https://doi.org/10.1016/j.compedu.2010.01.011.

14. Colbert, A., Yee, N., \& George, G. (2016). The Digital Workforce and the Workplace of the Future. Academy of Management Journal, 59(3), 731-739. http://dx.doi.org/10.5465/amj.2016.4003

15. Crossan, M., Lane, H., \& White, R. (1999). An organizational learning framework: From intuition to institution. Academy of Management Review, 24(3), 522-537. https://doi.org/10.5465/amr.1999.2202135

16. DeLone, W., \& McLean, E. (1992). Information systems success: The quest for the dependent variable. Information Systems Research, 3(1), 60-95. https://doi.org/10.1287/isre.3.1.60

17. Delone, W., \& McLean, E. (2003). The DeLone and McLean model of information systems success: a ten-year update. Journal of management information systems, 19(4), 9-30. http://dx.doi.org/10.1080/07421222.2003.11045748

18. DeLone, W., \& McLean, E. (2016). Information systems success measurement. Foundations and Trends in Information Systems, 2(1), 1-116. http://dx.doi.org/10.1561/2900000005

19. Etikan, I., Musa S. A., \& Alkassim R. S. (2016). Comparison of Convenience Sampling and Purposive Sampling. American Journal of Theoretical and Applied Statistics, 5(1), 1-4. https://doi.org/10.11648/j.ajtas.20160501.11

20. Fallon, C., \& Brown, S. (2003). E-learning Standards: A Guide to Purchasing, Developing, and Deploying Standards-conformant E-learning. CRC Press.

21. Fleming, J., Becker, K. and Newton, C. (2017), Factors for successful e-learning: does age matter?,Education + Training, 59(1), 76-89. https://doi.org/10.1108/ET-07-2015-0057

22. Gabelaia, I., \& Bucovetchi, O. (2020, April 30 - May 1). The Relevance of Corporate E-learning/Etraining for Job Development: Crafting Culture and Evolving Yourself [Conference paper]. The 16th International Scientific Conference eLearning and Software for Education, Bucharest, Romania. 10.12753/2066-026X-20-064

23. Garavan, T., Carbery, R., O'Malley, G., \& O'Donnell, D. (2010). Understanding participation in elearning in organizations: A large-scale empirical study of employees. International Journal of Training and Development,14(3), 155-168. https://doi.org/10.1111/j.1468-2419.2010.00349.x 
24. George, D., \& Mallery, P. (2016). IBM SPSS statistics 23 step by step: A simple guide and reference. Routledge.

25. Goswami, A. \& Dutta, S. (2016). Gender differences in technology usage: A literature review. Open Journal of Business and Management, 4, 51-59. http://dx.doi.org/10.4236/ojbm.2016.41006.

26. Gronseth, S., \& Hutchins, H. (2020). Flexibility in Formal Workplace Learning: Technology Applications for Engagement through the Lens of Universal Design for Learning. TechTrends, 64, 211-218. doi:10.1007/s11528-019-00455-6

27. Guner, H., \&Acarturk, C. (2018). The use and acceptance of ICT by senior citizens: a comparison of technology acceptance model (TAM) for elderly and young adults. Universal Access in the Information Society, 19(2), 311-330. doi:10.1007/s10209-018-0642-4

28. Haas, M., Criscuolo, P., \& George, G. (2014). Which Problems to Solve? Online Knowledge Sharing and Attention Allocation in Organizations. Academy of Management Journal, 58(3), 680-711. https://doi.org/10.5465/amj.2013.0263

29. Haikonen, T. (2016). Scenario analysis of corporate e-learning. (Publication ID: 467398) [Master's thesis, Aalto University]. Alto Doc.

30. Hauk, N., Hüffmeier, J. \& Krumm, S. (2018). Ready to be a Silver Surfer? A Meta-analysis on the Relationship Between Chronological Age and Technology Acceptance. Computers in Human Behavior, 84, 304-319, https://doi.org/10.1016/j.chb.2018.01.020.

31. Hester, A., \& Hutchins, H. (2016). Web 2.0 and Transfer: Trainers' Use of Technology to Support Employees' Learning Transfer on the Job. Performance Improvement Quarterly, 29(3), 231-255. https://doi.org/10.1002/piq.21225

32. Ifenthaler, D. (2018). How We learn at the Digital Workplace. In Ifenthaler, D. (Ed.), Digital Workplace Learning (pp.3-8). Springer. doi:10.1007/978-3-319-46215-8_1

33. Isaac, O., Mutahar, A., \& Ramayah, T. (2017). Examining the relationship between overall quality, user satisfaction and internet usage: An integrated individual, technological, organizational and social perspective. Asian Journal of Information Technology, 16(1), 100-124. https://doi.org/10.3923/ajit.2017.100.124

34. Islam, M. (2011). Effect of Demographic Factors on E-learning Effectiveness in a Higher Learning Institution in Malaysia. International Education Studies, 4(1), 112-121.

35. Kapo, A., Mujkic, A., Turulja, L., \& Kovacevic, J. (2020). Continuous E-learning at the Workplace: The Passport for the Future of Knowledge. Information Technology \& People, 28-56. https://doi.org/10.1108/ITP-04-2020-0223

36. Khechine, H., Lakhal, S., Pascot, D., \&Bytha, A. (2014). UTAUT model for blended learning: The role of gender and age in the intention to use webinars. Interdisciplinary Journal of E-Learning and Learning Objects, 10(1), 33-52.

37. Kim, S. (2008). Moderating effects of Job Relevance and Experience on mobile wireless technology acceptance: Adoption of a smartphone by individuals. Information \& Management, 45, 387-393. doi:10.1016/j.im.2008.05.002.

38. Larsen, T. J., Sørebø, A. M., \& Sørebø, Ø. (2009). The role of task-technology fit as users' motivation to continue information system use. Computers in Human Behavior, 25(3), 778-784. https://doi.org/10.1016/j.chb.2009.02.006

39. Lavrakas, P. (Ed). (2008). Encyclopedia of Survey Research Methods. SAGE Publications Inc.

40. Lenoue, M., Hall, T., \& Eighmy, M. (2011). Adult education and the social media revolution. Adult Learning, 22(2), 4-12. doi:10.1177/104515951102200201

41. Li, J., \& Herd, A. (2017). Shifting Practices in Digital Workplace Learning: An Integrated Approach to Learning, Knowledge Management, and Knowledge Sharing. Human Resource Development International, 20(3), 185-193. https://doi.org/10.1080/13678868.2017.1308460

42. Littlejohn, A., \& Margaryan, A. (2014). Technology-enhanced Professional Learning. In Billet S., Harteis C., \& Gruber H. (Eds.), International Handbook of Research in Professional and Practice-based Learning (pp. 1187-1212). Springer. doi:10.1007/978-94-017-8902-8_43

43. Migdadi, M. (2019). Organizational Learning Capability, Innovation and Organizational Performance. European Journal of Innovation Management, 34-56. doi:10.1108/EJIM-11-2018-0246

44. Montgomerie, K., Edwards, M., \& Thorn, K. (2016). Factors influencing online learning in an organisational context. Journal of Management Development, 35(10), 1313-1322. doi:10.1108/JMD-052016-0067

45. Nagahi, M., Hossain, N.\&Jaradat, R. (2019, Oct 23 - 26). Gender Differences in Practitioners' Preferences for Systems-Thinking Skills. American Society for Engineering Management 2019 International Annual Conference and 40th Annual Meeting, Philadelphia, PA, USA., Available at SSRN: https://ssrn.com/abstract=3435664

46. Oh, S., \& Han, H. (2018). Facilitating organisational learning activities: Types of organisational culture and their influence on organisational learning and performance. Knowledge Management Research \& Practice, 1-15. doi:10.1080/14778238.2018.1538668 
47. Oltra, V., López, S., \& Ortiz, M. (2018). The role of ontological learning levels in developing dynamic capabilities. International Journal of Learning and Change, 10(3), 242 - 258. https://doi.org/10.1504/IJLC.2018.093193

48. Prakash, V. (2018, December 22). Corporate Vs. Educational eLearning: What's The Big Difference? eLearning Industry. https://elearningindustry.com/subjects/elearning-articles/elearning-basics[Assessed: 14 March 2021].

49. Schaefer, T., Fabian, C., \& Kopp, T. (2019). The Dynamics of Online Learning at the Workplace: PeerFacilitated Social Learning and the Application in Practice. British Journal of Educational Technology, 51(4), 1406-1419. https://doi.org/10.1111/bjet.12894

50. Schaefer, T., Rahn, J., Kopp, T., Fabian, C., \& Brown, A. (2018). Fostering Online Learning at the Workplace: A Scheme to Identify and Analyse Collaboration Processes in Asynchronous Discussions. British Journal of Educational Technology, 50(3), 1354-1367. https://doi.org/10.1111/bjet.12617

51. Seufert, S., \& Meier, C. (2016). From E-learning to Digital Transformation: A Framework and Implications for L\&D. International Journal of Advanced Corporate Learning, 9(2), 27-33. http://dx.doi.org/10.3991/ijac.v9i2.6003

52. Tarhini, A., Elyas, T., Akour, M. A., \& Al-Salti, Z. (2016). Technology, Demographic Characteristics and E-learning Acceptance: A Conceptual Model Based on Extended Technology Acceptance Model. Higher Education Studies, 6(3), 72-89.

53. Tvenge, N., \& Martinsen, K. (2018). Integration of Digital Learning in Industry 4.0. Procedia Manufacturing, 23, 261 - 266. doi:10.1016/j.promfg.2018.04.027

54. van Kleef, G. A., \& Cheng, J. T. (2020). Power, status, and hierarchy: Current trends and future challenges. Current Opinion in Psychology, 33, 4 -13.https://doi.org/10.1016/j.copsyc.2020.03.011

55. Vančová, M., \& Kovačičová, Z. (2018). Sharing Knowledge and Information through Corporate Elearning. In N. Kryvinska, \& M. Gregus (Eds.), Agile Information Business (pp. 255-274). Springer. https://doi.org/10.1007/978-981-10-3358-2_8

56. Venkatesh, V., \&Bala, H. (2008). Technology acceptance model 3 and a research agenda on interventions.Decision Sciences, 39(2), 273-315. http://dx.doi.org/10.1111/j.1540-5915.2008.00192.x

57. Venkatesh, V., \& Morris, M. G. (2000). Why don't men ever stop to ask for directions? Gender, social influence, and their role in technology acceptance and usage behavior. MIS quarterly, 24(1), 115-139. http://dx.doi.org/10.2307/3250981

58. Venkatesh, V., Morris, M. G., Davis, G. B., \& Davis, F. D. (2003). User acceptance of information technology: Toward a unified view. MIS Quarterly, 27(3), 425-478.

59. Wagner, W.E. (2019). Using IBM SPSS Statistics for Research Methods and Social Science Statistics. ( $7^{\text {th }}$ ed.). SAGE Publications.

60. Wang, Y.S., Wang, H.Y., \& Shee, D. (2007). Measuring e-learning systems success in an organizational context: Scale development and validation. Computers in Human Behavior, 23(4), 1792-1808. https://doi.org/10.1016/j.chb.2005.10.006

61. Williams, C., Kilanski, K., \& Muller, C. (2014). Corporate diversity programs and gender inequality in the oil and gas industry. Work and Occupations, 41(4), 440-476. https://doi.org/10.1177/0730888414539172

62. Wongwatkit, C., Panjaburee, P., Srisawasdi, N. \&Seprum, P. (2020). Moderating Effects of Gender Differences on the Relationships between Perceived Learning Support, Intention to Use, and Learning Performance in a Personalized E-learning. Journal of Computer Education, 7, 229-255. doi:10.1007/s40692-020-00154-9

63. Wood, W. \&Eagly, A.H. (2009). Gender Identity. In Leary, M.R. \& Hoyle, R.H. (Eds.), Handbook of Individual Differences in Social Behavior (pp. 109 - 128). The Guilford Press.

64. Yang, B. (2019). Exploring e-learning experiences in a dynamic organizational learning environment: An interpretative phenomenological analysis of organizational e-learners in a multicultural consulting firm in Hong Kong (Publication No. 13814774) [Doctoral Thesis, Northeastern University]. ProQuest Dissertations Publishing. 